\title{
Halomonas rifensis sp. nov., an exopolysaccharide- producing, halophilic bacterium isolated from a solar saltern
}

Correspondence

Inmaculada Llamas

illamas@ugr.es

\author{
Hakima Amjres, ${ }^{1,2}$ Victoria Béjar, ${ }^{1}$ Emilia Quesada, ${ }^{1}$ Jamal Abrini $^{2}$ \\ and Inmaculada Llamas ${ }^{1}$
}

${ }^{1}$ Microbial Exopolysaccharide Research Group, Department of Microbiology, Faculty of Pharmacy, Cartuja Campus, University of Granada, 18071 Granada, Spain

${ }^{2}$ Biotechnology and Applied Microbiology Research Group, Department of Biology, Faculty of
Sciences, University Abdelmalek Essâadi, BP2121, 93002 Tetouan, Morocco

A polyphasic taxonomic study was conducted on strain $\mathrm{HK} 31^{\top}$, a moderately halophilic bacterium isolated from a solar saltern in Chefchaouen, Morocco. The strain was a Gram-reaction-negative, oxidase-positive rod, which was motile by means of peritrichous flagella. The strain required $\mathrm{NaCl}$ for growth and grew in salt concentrations (mixture of sea salts) of $0.5-20 \%(\mathrm{w} / \mathrm{v}$ ) (optimum $5-7.5 \%, w / v$ ), at $25-45{ }^{\circ} \mathrm{C}$ (optimum $32{ }^{\circ} \mathrm{C}$ ) and at $\mathrm{pH}$ 5-10 (optimum pH 6-9). Strain $\mathrm{HK} 31^{\top}$ did not produce acids from sugars and its metabolism was respiratory, using oxygen as terminal electron acceptor. The strain was positive for the accumulation of poly- $\beta$-hydroxyalkanoate granules and formed mucoid colonies due to the excretion of an exopolysaccharide. The DNA $\mathrm{G}+\mathrm{C}$ content was $61.5 \mathrm{~mol} \%$. 16S rRNA gene sequence analysis indicated that it belonged to the genus Halomonas in the class Gammaproteobacteria. The most phylogenetically related species was Halomonas anticariensis, with which strain $\mathrm{HK} 31^{\top}$ showed a $16 \mathrm{~S}$ rRNA gene sequence similarity of $96.48 \%$. Its major fatty acids were $\mathrm{C}_{18: 1} \omega 7 c, \mathrm{C}_{16: 0}, \mathrm{C}_{19: 0}$ cyclo $\omega 8 c$, $\mathrm{C}_{16: 1} \omega 7 \mathrm{c} /$ iso- $\mathrm{C}_{15: 0} 2-\mathrm{OH}$ and $\mathrm{C}_{12: 0} 3-\mathrm{OH}$ and the predominant respiratory lipoquinone was ubiquinone with nine isoprene units (Q-9). Based on the evidence provided in this study, strain HK31 ${ }^{\top}$ (=CECT $7698^{\top}=$ LMG $25695^{\top}$ ) represents a novel species of the genus Halomonas, for which the name Halomonas rifensis is proposed.
The family Halomonadaceae of the class Gammaproteobacteria, to date, contains 10 genera (Euzéby, 2010; Franzmann et al., 1988): Aidingimonas (Wang et al., 2009), Carnimonas (Garriga et al., 1998), Chromohalobacter (Ventosa et al., 1989), Cobetia (Arahal et al., 2002), Halomonas (Dobson \& Franzmann, 1996), Kushneria (Sánchez-Porro et al., 2009), Modicisalibacter (Ben Ali Gam et al., 2007) and Salinicola (Anan'ina et al., 2007), which are composed of halophilic and halotolerant bacteria, and Halotalea (Ntougias et al., 2007) and Zymobacter (Okamoto et al., 1993), which are composed of non-halophilic bacteria. The genus Halomonas currently contains more than 60 species of halophilic bacteria, most of which have been isolated from saline environments such as salterns, saline soils, seawater and marshes. Its members are Gram-negative, rod-shaped, non-sporulating chemo-organotrophs that have a predominantly respiratory metabolism, using oxygen or

The GenBank/EMBL/DDBJ accession number for the 16S rRNA gene sequence of strain $\mathrm{HK}-31^{\top}$ is $\mathrm{HM} 026177$

Three supplementary figures are available with the online version of this paper. nitrate as terminal electron acceptors. Some species of this genus are denitrifiers and a few of them have a fermentative metabolism. Members of the genus require 3-15\% (w/v) $\mathrm{NaCl}$ for optimum growth and can grow using a variety of compounds as sole carbon and energy sources (Mata et al., 2002; Vreeland, 2005; Arahal et al., 2007). Over the last two decades, some species of the genus Halomonas have provoked interest amongst biotechnologists because of their ability to produce exo-enzymes (Margesin \& Schinner, 2001; Ventosa \& Nieto, 1995), exopolysaccharides (Arias et al., 2003; Mata et al., 2006; Quesada et al., 2004) and other commercially valuable products.

During the course of ecological and taxonomic studies sampling hypersaline environments, a wide search was aimed at isolating and characterizing EPS-producing halophilic bacteria, which consequently led to the description of seven novel EPS-producing species of the genus Halomonas (Quesada et al., 1990; Bouchotroch et al., 2001; MartínezCánovas et al., 2004a, b; Martínez-Checa et al., 2005; González-Domenech et al., 2008a, b). As part of this study, a hypersaline habitat in Morocco was analysed, from which 


\section{Table 1. Characteristics that distinguish strain $\mathrm{HK}-31^{\top}$ from related type strains of the genus Halomonas}

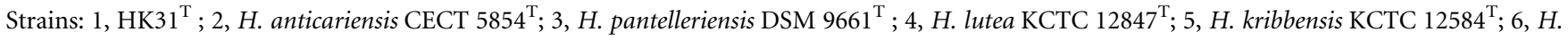
elongata ATCC $33173^{\mathrm{T}}$. All strains included in this table are negative for amylase activity, Tween 80 hydrolysis, haemolysis, respiration on nitrite, gas production from nitrate and growth on caprylate, DL-lactate, L-methionine and L-phenylalanine; positive for motility, growth on L-serine and cetrimide agar; and susceptible to rifampicin $(5 \mu \mathrm{g})$, nalidixic acid $(30 \mu \mathrm{g})$ and tobramycin $(10 \mu \mathrm{g})$. +, Positive; - , negative.

\begin{tabular}{|c|c|c|c|c|c|c|}
\hline Characteristic & 1 & 2 & 3 & 4 & 5 & 6 \\
\hline Morphology & Rod & Rod & Rod & Short rod & Coccus or short rod & Rod \\
\hline Cell size $(\mu \mathrm{m})$ & $0.8-1.0 \times 3.0-4.4$ & $0.75-1 \times 3.0-3.5$ & $0.4-0.7 \times 1.4-2.6^{*}$ & $0.7-0.8 \times 2.5-3$ & $1.4-1.8 \times 1.8-2.6 \ddagger$ & $0.8 \times 1.1$ \\
\hline $\begin{array}{l}\text { Exopolysaccharide } \\
\text { production }\end{array}$ & + & + & - & - & - & - \\
\hline Flagellation & Peritrichous & Peritrichous & Peritrichous ${ }^{\star}$ & Single flagellum $\dagger$ & Single flagellum $\ddagger$ & Polar/Peritrichous \\
\hline Range & $0.5-20$ & $0.5-15$ & $1-15$ & $1-20$ & $1-14$ & $0-20$ \\
\hline Optimum & $5-7.5$ & 7.5 & 5 & $5-10$ & 5 & $3-8$ \\
\hline \multicolumn{7}{|l|}{$\mathrm{pH}$ for growth } \\
\hline Range & $5-10$ & $6-9$ & $6-11$ & $5-9$ & $5.5-9.5$ & $5-10$ \\
\hline Optimum & $6-9$ & $7-8$ & 9 & 7.5 & $8-8.5$ & $6-8$ \\
\hline Gelatin & - & - & - & - & + & - \\
\hline DNA & - & + & - & - & - & + \\
\hline Casein & - & - & - & + & + & - \\
\hline Tween 20 & + & + & + & - & - & + \\
\hline Tyrosine & - & - & + & + & - & - \\
\hline Tyrosine pigment production & + & - & - & - & - & - \\
\hline Hydrogen sulfide production & - & - & - & - & - & - \\
\hline Lecithinase & + & - & + & - & - & + \\
\hline Phosphatase & + & + & - & - & - & + \\
\hline Urease & - & + & + & - & - & + \\
\hline Respiration on nitrate & + & - & + & + & + & - \\
\hline $\begin{array}{l}\text { L-Arabinose, D-fructose, } \\
\text { D-galactose }\end{array}$ & + & + & - & + & - & + \\
\hline Cellobiose & + & - & + & + & + & + \\
\hline Citrate & - & + & + & - & + & + \\
\hline Ethanol & + & + & + & + & + & - \\
\hline $\begin{array}{l}\text { L-Alanine, D-gluconate, } \\
\text { D-glucose, L-histidine, } \\
\text { D-mannitol, trehalose }\end{array}$ & + & + & + & + & - & + \\
\hline Glycerol & + & + & - & + & + & - \\
\hline Inositol, D-mannose & + & + & - & - & - & + \\
\hline Lactose & - & - & - & + & - & + \\
\hline Propionate & + & - & - & - & + & + \\
\hline Raffinose & + & - & - & - & - & + \\
\hline L-Rhamnose, sorbitol & + & - & + & + & - & + \\
\hline D-Salicin & + & - & + & - & - & - \\
\hline Starch & + & - & - & + & - & + \\
\hline
\end{tabular}


Table 1. cont.

\begin{tabular}{|c|c|c|c|c|c|c|}
\hline Characteristic & 1 & 2 & 3 & 4 & 5 & 6 \\
\hline L-Valine & - & - & - & - & - & + \\
\hline \multicolumn{7}{|l|}{ Susceptibility to: } \\
\hline Amoxicillin $(25 \mu \mathrm{g})$ & + & + & + & + & + & - \\
\hline Ampicillin $(10 \mu \mathrm{g})$ & + & + & + & + & + & - \\
\hline Erythromycin $(15 \mu \mathrm{g})$ & - & - & + & + & + & - \\
\hline Penicillin G $(10 \mu \mathrm{g})$ & + & - & - & + & + & - \\
\hline Polymyxin B (300 IU) & + & + & + & + & + & - \\
\hline Tetracycline $(30 \mu \mathrm{g})$ & + & + & - & + & + & - \\
\hline DNA G $+\mathrm{C}$ content $(\mathrm{mol} \%)$ & 61.5 & 61.4 & $65.0^{*}$ & $60.8 \dagger$ & $66 \ddagger$ & $64.2 \$$ \\
\hline
\end{tabular}

${ }^{*}$ Data from Romano et al. (1996).

$\dagger$ Data from Wang et al. (2008).

$¥$ Data from Jeon et al. (2007).

$\S$ Data from Vreeland et al. (1980).

strain $\mathrm{HK} 31^{\mathrm{T}}$ was isolated. The strain was subjected to a polyphasic taxonomic investigation, the results of which identified it as a novel species of the genus Halomonas.

Strain $\mathrm{HK} 31^{\mathrm{T}}$ was isolated from a soil sample taken from a solar saltern in the Brikcha Rural Commune village in Chefchaouen in the Rif Mountains, northern Morocco.

Recommendations of the proposed Minimal Standards for describing new taxa of the family Halomonadaceae (Arahal et al., 2007) were taken into account when performing phenotypic characterization on the novel strain. The miniaturized systems API $20 \mathrm{E}$ and API $20 \mathrm{NE}$ were used to study biochemical and nutritional traits; other tests were performed using traditional methods described previously (Ventosa et al., 1982; Quesada et al., 1983; Mata et al., 2002), the results of which are provided in Table 1 and in the species description.

The $\mathrm{G}+\mathrm{C}$ content of the genomic DNA was estimated from the midpoint melting temperature $\left(T_{\mathrm{m}}\right)$ value of the DNA (Marmur \& Doty, 1962), determined by the graphic method (Ferragut \& Leclerc, 1976), and calculated by using the equation of Owen \& Hill (1979). The DNA G+C content of strain $\mathrm{HK} 1^{\mathrm{T}}$ was $61.5 \mathrm{~mol} \%$, based on the $\mathrm{G}+\mathrm{C}$ content of reference DNA from Escherichia coli NCTC $9001^{\mathrm{T}}$ (50.9 mol\%) (Owen \& Pitcher, 1985).

Phylogenetic analysis based on 16S rRNA gene sequences was performed following standard procedures. The $16 \mathrm{~S}$ rRNA gene of strain $\mathrm{HK} 31^{\mathrm{T}}$ was amplified by PCR and the product was cloned into pGEM-T cloning vector (Promega) according to the manufacturer's instructions and transformed into E. coli DH5- $\alpha$. The 16S rRNA gene sequence (1471 bp) was then determined by primer walking using a BigDye Terminator Cycle Sequencing kit in an ABI 3100 DNA sequencer (Applied Biosytems). The sequence was then compared with reference 16S rRNA gene sequences available in the GenBank database using BLAST. Pairwise 16S rRNA gene sequence identities were calculated using the EzTaxon server (http://www.eztaxon.org/; Chun et al., 2007).
Phylogenetic analyses were performed using MEGA version 4 software (Tamura et al., 2007) after multiple alignments of the data in the CLUSTAL W (Thompson et al., 1997) and PHYLIP version 3.69 (Felsenstein, 1981) programs. Phylogenetic analysis was carried out as recommended by Arahal et al., 2007. Distances were calculated and clustering was determined, using the neighbour-joining, maximum-parsimony and maximum-likelihood methods to reconstruct phylogenetic trees supported by bootstrap values based on 1000 replications. The gene fragment analysed contained the 18 signature nucleotides defined for members of the family Halomonadaceae and the four signature nucleotides defined for the genus Halomonas (Dobson \& Franzmann, 1996). Phylogenetic trees based on the neighbour-joining method (Fig. 1) and the maximum-likelihood and maximumparsimony methods (Supplementary Figs S1 and S2, available in IJSEM Online) all showed a highly similar tree topology, indicating that strain $\mathrm{HK} 31^{\mathrm{T}}$ belongs to the genus Halomonas. Strain $\mathrm{HK} 31^{\mathrm{T}}$ showed the highest $16 \mathrm{~S}$ rRNA gene sequence similarity to Halomonas anticariensis CECT $5854^{\mathrm{T}}(96.48 \%)$. Other species in the same clade included $H$. pantellerensis, $H$. kribbensis and $H$. lutea, with which strain $\mathrm{HK} 1^{\mathrm{T}}$ shared 96.1, 95.7 and $95.4 \%$ 16S rRNA gene sequence similarity, respectively. Evolutionary distances, including a correction factor for reverse mutations (Jukes \& Cantor, 1969), were calculated for sequence pairs by using a 'mask' (Lane, 1991) for dissimilar or uncertain nucleotide positions.

Transmission electron microscopy was used, as described by Bouchotroch et al. (2001), to determine cell size, cell morphology and the presence of peritrichous flagella (Supplementary Fig. S3). For fatty acid and quinones analyses, cells were grown at $32{ }^{\circ} \mathrm{C}$ in $\mathrm{MY}$ medium (Moraine \& Rogovin, 1966) with $7.5 \%(\mathrm{w} / \mathrm{v})$ sea-salt solution (Rodríguez-Valera et al., 1981). Fatty acids and quinones were analysed at the DSMZ by using highresolution GLC and HPLC, respectively. Strain HK31 ${ }^{\mathrm{T}}$ contained a combination of fatty acids characteristic of species of the genus Halomonas (Dobson \& Franzmann, 


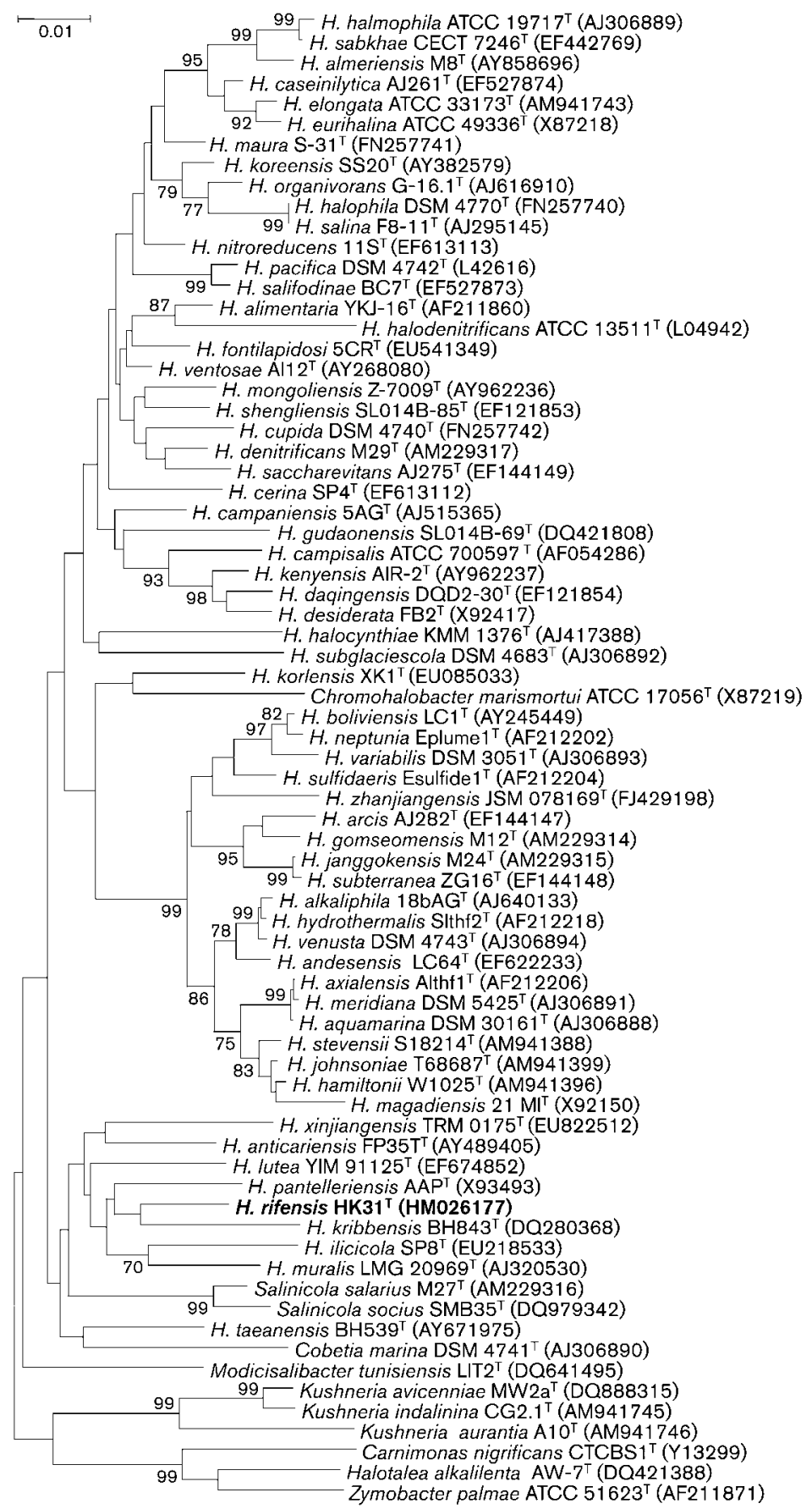

Fig. 1. Phylogenetic tree based on $16 \mathrm{~S}$ rRNA gene sequences, showing the position of strain $\mathrm{HK} 31^{\top}$ compared with other members of the family Halomonadaceae. The tree was obtained using the neighbour-joining algorithm. Bar, 1\% sequence divergence. Bootstrap values $>70 \%$ (based on 1000 replications) are shown at branch points.

1996). The major fatty acids were $\mathrm{C}_{18: 1} \omega 7 c(38.25 \%)$, $\mathrm{C}_{16: 0}(26.73 \%), \mathrm{C}_{19: 0}$ cyclo $\omega 8 c(14.85 \%), \mathrm{C}_{16: 1} \omega 7 c /$ iso$\mathrm{C}_{15: 0} 2-\mathrm{OH}(6.63 \%)$ and $\mathrm{C}_{12: 0} 3-\mathrm{OH}(5.85 \%)$. Other fatty acids included $\mathrm{C}_{14: 0}(0.23 \%), \mathrm{C}_{17: 0}$ cyclo $(0.35 \%), \mathrm{C}_{18: 0}$ $(0.88 \%), \mathrm{C}_{18: 1} \omega 5 c(0.21 \%)$ and $\mathrm{C}_{20: 2} \omega 6,9 c(0.25 \%)$. Analysis of the quinones showed that the novel strain contained ubiquinone $9(\mathrm{Q}-9)$ as the predominant respiratory lipoquinone $(100 \%)$.

Based on the evidence provided herein, strain $\mathrm{HK} 31^{\mathrm{T}}$ represents a novel species of the genus Halomonas, for which the name Halomonas rifensis is proposed.

\section{Description of Halomonas rifensis sp. nov.}

Halomonas rifensis (ri.fen' sis. N.L. adj. rifensis pertaining to the Rif mountains in northern Morocco, where the strain was isolated).

Cells are Gram-reaction-negative rods, $0.8-1.0 \times 3.0-$ $4.4 \mu \mathrm{m}$, that occur either singly or in pairs, are motile by peritrichous flagella, produce exopolysaccharide, accumulate poly- $\beta$-hydroxyalkanoate and do not form endospores. Forms circular, convex, creamy-white colonies. Growth pattern in liquid medium is uniform. Moderately halophilic; capable of growth in salt concentrations (mixture 
of sea salts) of $0.5-20 \%(\mathrm{w} / \mathrm{v})$ (optimum $5-7.5 \%$, w/v); incapable of growing without $\mathrm{NaCl}$. Grows at $25-45{ }^{\circ} \mathrm{C}$ (optimum $32{ }^{\circ} \mathrm{C}$ ) and at $\mathrm{pH}$ 5-10 (optimum pH 6-9). Does not produce acid from any of the sugars or alcohols tested, including L-arabinose, amygdalin, D-glucose, inositol, Dmannitol, melibiose, L-rhamnose, sucrose and D-sorbitol. Chemoorganotrophic and produces catalase and oxidase. Metabolism is respiratory with oxygen and nitrate but not with nitrite and fumarate as terminal electron acceptors. Indole, methyl red, Voges-Proskauer and ONPG tests are negative. Does not produce hydrogen sulfide from L-cysteine. Aerobic nitrate reduction is negative. Hydrolyses Tween 20 but not casein, DNA, gelatin, Tween 80 or tyrosine. Produces pigment from tyrosine. Produces lecithinase, phosphatase and tryptophan deaminase but not amylase, arginine dihydrolase, haemolysin, lysine decarboxylase, ornithine decarboxylase or urease. Grows on MacConkey agar and cetrimide agar. The following compounds are utilized as sole carbon and energy sources: acetate, adonitol, L-arabinose, L-aspartate, benzoate, cellobiose, ethanol, formate, fumarate, D-fructose, D-galactose, D-gluconate, D-glucose, D-glutamate, glycerol, hippurate, DL- $\beta$-hydroxybutyrate, inositol, malate, malonate, maltose, D-mannitol, D-mannose, melezitose, melibiose, propionate, pyruvate, raffinose, L-rhamnose, Dsalicin, sorbitol, starch, succinate, trehalose and D-xylose. The following compounds are not used as sole carbon and energy sources: adipic acid, aesculin, caprylate, citrate, DL-lactate, lactose, phenylacetic acid, 2-propanol, ribose, D-salicin and tartrate. $\mathrm{N}$-acetylglucosamine, L-alanine, creatine, L-histidine, L-isoleucine, L-leucine, L-proline, L-serine and L-threonine are used as sole sources of carbon, nitrogen and energy. L-arginine, L-cysteine, L-lysine, L-methionine, L-ornithine, L-phenylalanine, L-tryptophan and L-valine are not used as sole sources of carbon, nitrogen and energy. Susceptible to ( $\mu$ g unless stated otherwise) amoxicillin (25), ampicillin (10), cefalothin (30), gentamicin (10), nalidixic acid (30), penicillin G (10), polymyxin B (300 IU), tetracycline (30), tobramycin (10), rifampicin (5) and sulphamide (300) and resistant to erythromycin (15). The principal fatty acids are $\mathrm{C}_{18: 1} \omega 7 c$, $\mathrm{C}_{16: 0}, \mathrm{C}_{19: 0}$ cyclo $\omega 8 c, \mathrm{C}_{16: 1} \omega 7 c /$ iso- $\mathrm{C}_{15: 0} 2-\mathrm{OH}$ and $\mathrm{C}_{12: 0} 3-$ $\mathrm{OH}$. The predominant respiratory quinone is Q-9.

The type strain, HK31 ${ }^{\mathrm{T}}\left(=\mathrm{CECT} 7698^{\mathrm{T}}=\mathrm{LMG} 25695^{\mathrm{T}}\right)$, was isolated from a solar saltern in Chefchaouen in the Rif Mountains, Morocco. The DNA G $+\mathrm{C}$ content of the type strain is $61.5 \mathrm{~mol} \%$ ( $T_{m}$ method).

\section{Acknowledgements}

This research was supported by grants from the Spanish Ministerio de Educación y Ciencia (CGL 2005-05947; CGL2008-02399/BOS), the Consejería de Educación Ciencia y Empresa of the Andalucian Regional Government (P06-CVI-01850) and the Plan Andaluz de Investigación. H. A. was supported by a postgraduate grant from the Foundation L'ORÉAL/UNESCO Co-Sponsored Fellowships for Young Women in Life Sciences (Paris, France) and a grant from the National Center for Scientific Research and Technology in Morocco (CNRST). We thank Concepción Hernández and $\mathrm{M}^{\mathrm{a}}$ José Martínez Guerrero of the Centro de Instrumentación Científica (University of
Granada) for their expertise in the microscopic analysis. We also thank our colleague Dr J. Trout for revising our English text.

\section{References}

Anan'ina, L. N., Plotnikova, E. G., Gavrish, E. lu., Demakov, V. A. \& Evtushenko, L. I. (2007). Salinicola socius gen. nov., sp. nov., a moderately halophilic bacterium from a naphthalene-utilizing microbial association. Mikrobiologiia 76, 324-330 (original Russian text, pp. 369-376).

Arahal, D. R., Castillo, A. M., Ludwig, W., Schleifer, K. H. \& Ventosa, A. (2002). Proposal of Cobetia marina gen. nov., comb. nov., within the family Halomonadaceae, to include the species Halomonas marina. Syst Appl Microbiol 25, 207-211.

Arahal, D. R., Vreeland, R. H., Litchfield, C. D., Mormile, M. R., Tindall, B. J., Oren, A., Béjar, V., Quesada, E. \& Ventosa, A. (2007). Recommended minimal standards for describing new taxa of the family Halomonadaceae. Int J Syst Evol Microbiol 57, 2436-2446.

Arias, S., del Moral, A., Ferrer, M. R., Tallon, R., Quesada, E. \& Béjar, V. (2003). Mauran, an exopolysaccharide produced by the halophilic bacterium Halomonas maura, with a novel composition and interesting properties for biotechnology. Extremophiles 7, 319-326.

Ben Ali Gam, Z., Abdelkafi, S., Casalot, L., Tholozan, J. L., Oueslati, R. \& Labat, M. (2007). Modicisalibacter tunisiensis gen. nov., sp. nov., an aerobic, moderately halophilic bacterium isolated from an oilfieldwater injection sample, and emended description of the family Halomonadaceae Franzmann et al. 1989 emend Dobson and Franzmann 1996 emend. Ntougias et al. 2007. Int J Syst Evol Microbiol 57, 2307-2313.

Bouchotroch, S., Quesada, E., del Moral, A., Llamas, I. \& Béjar, V. (2001). Halomonas maura sp. nov., a novel moderately halophilic, exopolysaccharide-producing bacterium. Int J Syst Evol Microbiol 51, 1625-1632.

Chun, J., Lee, J.-H., Jung, Y., Kim, M., Kim, S., Kim, B. K. \& Lim, Y. W. (2007). EzTaxon: a web-based tool for the identification of prokaryotes based on $16 \mathrm{~S}$ ribosomal RNA gene sequences. Int J Syst Evol Microbiol 57, 2259-2261.

Dobson, S. J. \& Franzmann, P. D. (1996). Unification of the genera Deleya (Bauman et al., 1993), Halomonas (Vreeland et al., 1980), and Halovibrio (Fendrich, 1988) and the species Paracoccus halodenitrificans (Robinson and Gibbons, 1952) into a single genus, Halomonas, and placement of the genus Zymobacter in the family Halomonadaceae. Int J Syst Bacteriol 46, 550-558.

Euzéby, J. P. (2010). List of Prokaryotic Names with Standing in Nomenclature. http://www.bacterio.cict.fr.

Felsenstein, J. (1981). Evolutionary trees from DNA sequences: a maximum likelihood approach. J Mol Evol 17, 368-376.

Ferragut, C. \& Leclerc, H. (1976). Étude comparative des méthodes de détermination du $T_{\mathrm{m}}$ de l'ADN bacterien. Ann Microbiol 127, 223 235 (in French).

Franzmann, P. D., Wehmeyer, U. \& Stackebrandt, E. (1988). Halomonadaceae fam. nov., a new family of Proteobacteria to accommodate the genera Halomonas and Deleya. Syst Appl Microbiol 11, 16-19.

Garriga, M., Ehrmann, M. A., Arnau, J., Hugas, M. \& Vogel, R. F. (1998). Carnimonas nigrificans gen. nov., sp. nov., a bacterial causative agent for black spot formation on cured meat products. Int J Syst Bacteriol 48, 677-686.

González-Domenech, C. M., Béjar, V., Martínez-Checa, F. \& Quesada, E. (2008a). Halomonas nitroreducens sp. nov., a novel nitrate- and nitrite-reducing species. Int J Syst Evol Microbiol 58, 872 876. 
González-Domenech, C. M., Martínez-Checa, F., Quesada, E. \& Béjar, V. (2008b). Halomonas cerina sp. nov., a moderately halophilic, denitrifying, exopolysaccharide-producing bacterium. Int J Syst Evol Microbiol 58, 803-809.

Jeon, C. O., Lim, J. M., Lee, J. R., Lee, G. S., Park, D. J., Lee, J. C., Oh, H. W. \& Kim, C. J. (2007). Halomonas kribbensis sp. nov., a novel moderately halophilic bacterium isolated from a solar saltern in Korea. Int J Syst Evol Microbiol 57, 2194-2198.

Jukes, T. H. \& Cantor, C. R. (1969). Evolution of protein molecules. In Mammalian Protein Metabolism, vol. 3, pp. 21-132. Edited by H. N. Munro. New York: Academic Press.

Lane, D. J. (1991). 16S/23S rRNA sequencing. In Nucleic Acid Techniques in Bacterial Systematics, pp. 115-175. Edited by E. Stackebrandt \& M. Goodfellow. Chichester: John Wiley.

Margesin, R. \& Schinner, F. (2001). Potential of halotolerant and halophilic microorganisms for biotechnology. Extremophiles 5, 73-83.

Marmur, J. \& Doty, P. (1962). Determination of the base composition of deoxyribonucleic acid from its thermal denaturation temperature. J Mol Biol 5, 109-118.

Martínez-Cánovas, M. J., Béjar, V., Martínez-Checa, F. \& Quesada, E. (2004a). Halomonas anticariensis sp. nov., from Fuente de Piedra, a saline-wetland wildfowl reserve in Malaga, southern Spain. Int J Syst Evol Microbiol 54, 1329-1332.

Martínez-Cánovas, M. J., Quesada, E., Llamas, I. \& Béjar, V. (2004b). Halomonas ventosae sp. nov., a moderately halophilic, denitrifying, exopolysaccharide-producing bacterium. Int J Syst Evol Microbiol 54, 733-737.

Martínez-Checa, F., Béjar, V., Martínez-Cánovas, M. J., Llamas, I. \& Quesada, E. (2005). Halomonas almeriensis sp. nov., a moderately halophilic, exopolysaccharide-producing bacterium from Cabo de Gata, Almería, south-east Spain. Int J Syst Evol Microbiol 55, 20072011.

Mata, J. A., Martínez-Cánovas, J., Quesada, E. \& Béjar, V. (2002). A detailed phenotypic characterisation of the type strains of Halomonas species. Syst Appl Microbiol 25, 360-375.

Mata, J. A., Béjar, V., Llamas, I., Arias, S., Bressollier, P., Tallon, R., Urdaci, M. C. \& Quesada, E. (2006). Exopolysaccharides produced by the recently described halophilic bacteria Halomonas ventosae and Halomonas anticariensis. Res Microbiol 157, 827-835.

Moraine, R. A. \& Rogovin, P. (1966). Kinetics of polysaccharide B1459 fermentation. Biotechnol Bioeng 8, 511-524.

Ntougias, S., Zervakis, G. I. \& Fasseas, C. (2007). Halotalea alkalilenta gen. nov., sp. nov., a novel osmotolerant and alkalitolerant bacterium from alkaline olive mill wastes, and emended description of the family Halomonadaceae Franzmann et al. 1989, emend. Dobson and Franzmann 1996. Int J Syst Evol Microbiol 57, 1975-1983.

Okamoto, T., Taguchi, H., Nakamura, K., Ikenaga, H., Kuraishi, H. \& Yamasato, K. (1993). Zymobacter palmae gen. nov., sp. nov., a new ethanol-fermenting peritrichous bacterium isolated from palm sap. Arch Microbiol 160, 333-337.

Owen, R. J. \& Hill, L. R. (1979). The estimation of base compositions, base pairing and genome size of bacterial deoxyribonucleic acids. In Identification Methods for Microbiologists, 2nd edn, pp. 277-296. Edited by F. A. Skinner \& D. W. Lovelock. London: Academic Press.

Owen, R. J. \& Pitcher, D. (1985). Current methods for estimating DNA composition and levels of DNA-DNA hybridization. In Chemical Methods in Bacterial Systematics, pp. 67-93. Edited by M. Goodfellow \& E. Minnikin. London: Academic Press.

Quesada, E., Ventosa, A., Rodríguez-Valera, F. \& RamosCormenzana, A. (1983). Numerical taxonomy of moderately halophilic Gram-negative bacteria from hypersaline soils. J Gen Microbiol 129, 2649-2657.

Quesada, E., Valderrama, M. J., Béjar, V., Ventosa, A., Gutierrez, M. C., Ruiz-Berraquero, F. \& Ramos-Cormenzana, A. (1990). Volcaniella eurihalina gen. nov., sp. nov., a moderately halophilic nonmotile Gram-negative rod. Int J Syst Bacteriol 40, 261-267.

Quesada, E., Béjar, V., Ferrer, M. R., Calvo, C., Llamas, I., MartínezCheca, F., Arias, S., Ruiz-Garcia, C., Páez, R. \& other authors (2004). Moderately halophilic, exopolysaccharide-producing bacteria. In Halophilic Microorganisms, pp. 297-314. Edited by A. Ventosa. Heildelberg: Springer.

Rodríguez-Valera, F., Ruiz-Berraquero, F. \& Ramos-Cormenzana, A. (1981). Characteristics of the heterotropic bacterial populations in hypersaline environments of different salt concentrations. Microb Ecol 7, 235-243.

Romano, I., Nicolaus, B., Lama, L., Manca, M. C. \& Gambacorta, A. (1996). Characterization of a haloalkalophilic strictly aerobic bacterium, isolated from Pantelleria island. Syst Appl Microbiol 19, 326-333.

Sánchez-Porro, C., de la Haba, R. R., Soto-Ramírez, N., Márquez, M. C., Montalvo-Rodríguez, R. \& Ventosa, A. (2009). Description of Kushneria aurantia gen. nov., sp. nov., a novel member of the family Halomonadaceae, and a proposal for reclassification of Halomonas marisflavi as Kushneria marisflavi comb. nov., of Halomonas indalinina as Kushneria indalinina comb. nov. and of Halomonas avicenniae as Kushneria avicenniae comb. nov. Int J Syst Evol Microbiol 59, 397-405.

Tamura, K., Dudley, J., Nei, M. \& Kumar, S. (2007). MEGA4: molecular evolutionary genetics analysis (MEGA) software version 4.0. Mol Biol Evol 24, 1596-1599.

Thompson, J. D., Gibson, T. J., Plewniak, K., Jeanmougin, F. \& Higgins, D. G. (1997). The CLUSTAL_X window interface: flexible strategies for multiple sequence alignments aided by quality analysis tools. Nucleic Acids Res 25, 4876-4882.

Ventosa, A. \& Nieto, J. J. (1995). Biotechnological applications and potentialities of halophilic microorganisms. World J Microbiol Biotechnol 11, 85-94.

Ventosa, A., Quesada, E., Rodríguez-Valera, F., Ruíz-Berraquero, F. \& Ramos-Cormenzana, A. (1982). Numerical taxonomy of moderately halophilic Gram-negative rods. J Gen Microbiol 128, 1959-1968.

Ventosa, A., Gutierrez, M. C., Garcia, M. T. \& Ruiz-Berraquero, F. (1989). Classification of "Chromobacterium marismortui" in a new genus, Chromohalobacter gen. nov., as Chromohalobacter marismortui comb. nov., nom. rev. Int J Syst Bacteriol 39, 382-386.

Vreeland, R. H. (2005). Genus I. Halomonas. In Bergey's Manual of Systematic Bacteriology, The Proteobacteria, part B: The Gammaproteobacteria, 2nd edn, vol. 2, pp. 300-303. Edited by D. J. Brenner, N. R. Krieg, J. T. Staley \& G. M. Garrity. New York: Springer.

Vreeland, R. H., Litchfield, C. D., Martin, E. L. \& Elliot, E. (1980). Halomonas elongata, a new genus and species of extremely salttolerant bacteria. Int J Syst Bacteriol 30, 485-495.

Wang, Y., Tang, S. K., Lou, K., Mao, P. H., Jin, X., Jiang, C. L., Xu, L. H. \& Li, W. J. (2008). Halomonas lutea sp. nov., a moderately halophilic bacterium isolated from a salt lake. Int J Syst Evol Microbiol 58, 20652069.

Wang, Y., Tang, S. K., Lou, K., Lee, J. C., Jeon, C. O., Xu, L. H., Kim, C. J. \& Li, W. J. (2009). Aidingimonas halophila gen. nov., sp. nov., a moderately halophilic bacterium isolated from a salt lake. Int J Syst Evol Microbiol 59, 3088-3094. 